\title{
Conceptualising the professional identity of industrial or organisational psychologists within the South African context
}

\begin{tabular}{|c|c|}
\hline \multicolumn{2}{|c|}{$\begin{array}{l}\text { Authors: } \\
\text { Llewellyn E. van Zyl }^{1,2} \\
\text { Elzabe Ne }^{3} \\
\text { Marius W. Stander } \\
\text { Sebastiaan Rothmann }(\mathrm{Sr})^{1}\end{array}$} \\
\hline $\begin{array}{l}\text { Affiliations: } \\
\text { 'Optentia Res } \\
\text { Area, Departm } \\
\text { Psychology, Nc } \\
\text { University, Sou }\end{array}$ & $\begin{array}{l}\text { earch Focus } \\
\text { ent of Industrial } \\
\text { orth-West } \\
\text { th Africa }\end{array}$ \\
\hline \multicolumn{2}{|c|}{$\begin{array}{l}{ }^{2} \text { Department of Human } \\
\text { Resource Management, } \\
\text { University of Twente, The } \\
\text { Netherlands }\end{array}$} \\
\hline \multicolumn{2}{|c|}{$\begin{array}{l}{ }^{3} \text { Department of Industrial } \\
\text { Psychology, University of } \\
\text { South Africa, South Africa }\end{array}$} \\
\hline \multicolumn{2}{|c|}{$\begin{array}{l}\text { Corresponding author: } \\
\text { Llewellyn E. van Zyl, } \\
\text { llewellyn101@gmail.com }\end{array}$} \\
\hline $\begin{array}{l}\text { Dates: } \\
\text { Received: } 19 \\
\text { Accepted: } 18 \\
\text { Published: } 02\end{array}$ & $\begin{array}{l}\text { May } 2016 \\
\text { Aug. } 2016 \\
\text { Dec. } 2016\end{array}$ \\
\hline \multicolumn{2}{|c|}{$\begin{array}{l}\text { How to cite this article: } \\
\text { Van Zyl, L.E., Nel, E., Stander, } \\
\text { M.W., \& Rothmann, S. (2016). } \\
\text { Conceptualising the } \\
\text { professional identity of } \\
\text { industrial or organisational } \\
\text { psychologists within the } \\
\text { South African context. SA } \\
\text { Journal of Industrial } \\
\text { Psychology/SA Tydskrif vir } \\
\text { Bedryfsielkunde, 42(1), } \\
\text { a1326. http://dx.doi. } \\
\text { org/10.4102/sajip.v42i1.1379 }\end{array}$} \\
\hline \multicolumn{2}{|c|}{$\begin{array}{l}\text { Copyright: } \\
\text { (c) 2016. The Authors. } \\
\text { Licensee: AOSIS. This } \\
\text { is licensed under the } \\
\text { Creative Commons } \\
\text { Attribution License. }\end{array}$} \\
\hline \multicolumn{2}{|l|}{ Read online: } \\
\hline 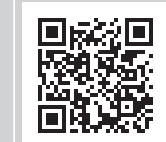 & $\begin{array}{l}\text { Scan this QR } \\
\text { code with your } \\
\text { smart phone or } \\
\text { mobile device } \\
\text { to read online. }\end{array}$ \\
\hline
\end{tabular}

Orientation: Lack in congruence amongst industrial and organisational psychologists (IOPs) as to the conceptualisation of its profession poses a significant risk as to the relevance, longevity and professional identity of the profession within the South African context.

Research purpose: This study aimed to explore the professional identity of IOPs within the South African context. Specifically, the aim of this study was four-fold: (1) to develop a contemporary definition for IOP, (2) to investigate IOP roles, (3) to determine how the profession should be labelled and (4) to differentiate IOP from human resource management (HRM) from IOPs' perspectives within South Africa.

Motivation for the study: IOPs do not enjoy the same benefits in stature or status as other professions such as medicine, finances and engineering in the world of work. IOPs need to justify its relevance within organisational contexts as a globally shared understanding of 'what it is', 'what it does' and 'what makes it different from other professions', which is non-existent. In order to enhance its perceived relevance, clarity as to IOPs professional identity is needed.

Research design, approach and method: A post-positivistic qualitative content analytic and descriptive research design was employed in this study. Data from practising industrial and organisational psychology (IOP) within South Africa $(N=151)$ were gathered through an electronic web-based survey and were analysed through thematic content analysis.

Main findings: The results indicate that IOP in South Africa seeks to optimise the potential of individuals, groups, organisations and the community by implementing scientific processes to support both individual and organisational wellness and sustainability. 'Work Psychology' was considered a more fitting professional designation or label than industrial and/or organisational psychology. The industrial psychologist's major roles related to the well-being and development of employees. A clear distinction between a more dynamic, pro-active approach of IOP compared to a more transactional approach of HRM was also evident. IOP within South Africa appears to have a community development function.

Practical/managerial implications: The longevity, relevance and impact of IOP as a profession requires alignment amongst practitioners as to shared common professional identity.

Contribution/value-add: This study provides a contemporary understanding of the roles, functions, labels and unique value proposition of industrial and organisational psychology within the South African context.

\section{Introduction}

Industrial and organisational psychology $(\mathrm{IOP})^{1}$ as a unique, stand-alone professional discipline, with a clearly articulated and collectively accepted value proposition (Coetzee \& Van Zyl, 2014a), has been plagued with questions as to its relevance, professional visibility, distinction from other professions and the lack of shared professional identity in recent years (Aguinis, Bradley \& Brodersen, 2014; Morelli, Illingworth \& Handler, 2015; Van Zyl, Stander \& Coetzee, 2013a). As there is little consensus as to: (1) the attributes which are central, enduring and distinctive to the field (Ryan \& Ford, 2010), (2) the roles and/or functions of IOPs (Morelli et al., 2015), (3) how the profession and the discipline should be labelled and (4) how IOP can maintain its distinctiveness from other professions (e.g. Human Resources and/or Psychology) (Avedon \& Grabow, 2010), it has been marginalised over time (Lefkowitz, 2016). As such IOP practitioners often need to justify the reasons for their existence within organisations (Coetzee \& Van Zyl, 2014a; Van Vuuren, 2010; 
Van Zyl et al., 2013a) since their primary contributions do not have a measurable impact on the organisation's bottom line (Van Zyl et al., 2013a). Further, stemming from the broad scope of professional practice within the South African context, the lack of a professionally shared definition, professional designation (or 'title' and/or 'label'), and functional roles of IOPs amongst registered practitioners could have resulted in a professional identity crisis (Campana, 2014; Coetzee \& Van Zyl, 2014a; Van Zyl, 2013a).

Because a shared identity of IOP is lacking within South Africa, IOP practitioners find it difficult to articulate their value proposition to stakeholders (Strümpher, 2007). This results in the development of new 'definitions' and professional designations and/or titles (e.g. coaching psychologists, consulting psychologists, and behavioural psychotechnicians) in an attempt to differentiate the professional practice of IOP from other professions such as clinical psychology, human resource management (HRM), and even amongst IOP practitioners. Similarly, the lack of clearly defined boundaries between the roles and functions of industrial psychologists and HRM practitioners, and the associative overlap thereof reinforces the self-perceived professional identity crisis (Benjamin \& Louw-Potgieter, 2008; Van Zyl, Deacon \& Rothmann, 2010).

The abovementioned factors are major distractors to the longevity of the profession and are core attributors to IOP's professional identity crisis for four reasons: Firstly, contemporary definitions of IOP are not clear, too general and vague (Chamda, 2013; Ryan \& Ford, 2010; Van Zyl et al., 2013a). This contributes to an inaccurate representation relating to the meaning of the profession and results in confusion associated with the jurisdiction of the IOPs' professional areas of practice (Benjamin, 2005). In general, IOP is defined as the application of scientific methods and principles of psychology to the workplace (Spector, 2012) in order to solve work-related problems (Jex \& Britt, 2014; Van Vuuren, 2010). Within the South African context, the Health Professions Council of South Africa (HPCSA) defines the practice of industrial psychology as 'applying the principles of psychology to issues related to the work situation of relatively well-adjusted adults in order to optimise individual, group and organisational well-being and effectiveness' (HPCSA, 2005, Form 244). Whilst these IOP definitions contain certain commonalities, the specific psychological acts that fall within the scope of practice of IOPs are unclear. The HPCSA (2005) provides general guidelines as to the professional practice domains of IOPs: planning, developing and applying paradigms, theories, models, constructs and principles of psychology at work in order to understand, modify and enhance individual, group and organisational behaviour effectively (Coetzee \& Van Zyl, 2014b). Furthermore, IOPs perform psychometric and other assessments and facilitate individual and group processes for effective organisational functioning. IOPs advise on the development of policies, design, manage and evaluate intervention programmes, and train and supervise student and other IOPs. Lastly, the scope of practice includes designing and developing strategies in consumer behaviour, developing interventions to ameliorate poor performance in work settings and designing and implementing programmes based on understanding ergonomics (The Health Professions Act 56 of 1974; 2010). From the definitions above it is evident that contemporary definitions for IOP are broad, unclear and could describe the scope of any practitioner working with people in organisational contexts such as HRM practitioners, managers or management consultants (Van Zyl et al., 2013b).

Secondly, recurring issues regarding the professional distinction, title or label of the profession remains a challenge to the identity of the profession (Cooper-Thomas \& Wright, 2008). Internationally, the profession was originally labelled industrial psychology and subsequently renamed as IOP in 1973 (Highhouse \& Schmitt, 2012; Koppes, 2014). Although the name of the profession in South Africa is not generally agreed-upon (Bergh, 2009) the term 'industrial psychology' is generally used to describe the field of the IOP profession because of the HPCSA's registration category for registered psychologists within industry (Benjamin \& Louw-Potgieter, 2008; Guest \& Kriek, 2008; Veldsman, 2001). Different professional distinctions or labels for the profession have been developed across countries and include terms such as 'vocational psychology', 'occupational psychology', 'work psychology' (Chamda, 2013; Warr, 2007), and 'business psychology' (Highhouse \& Schmitt, 2012). Research indicates that professional distinctions, titles or labels may be influenced by social experiences, education, the working environment (Cohen-Scali, 2003) and changes or developments within an individual's career (Dobrow \& Higgins, 2005). Further, the rapid evolution of IOP, coupled with the resultant professional identity crisis (Van Zyl et al., 2013a) may result in the development of various professional distinctions, titles or labels in an attempt to establish a professional identity that is distinct from other associative fields (Strümpher, 2007). The lack in congruent professional distinctions or titles may be based on the need to create a unique professional identity that differentiates between IOPs and other practitioners. IOPs may use different professional titles to clearly convey what the profession entails, the type of professional services offered, as well as the potential value-add of these service (in contrast to other practitioners).

Thirdly, the variation which exists relating to the professional distinctions or labels creates ambiguity with regard to the roles of the IOP practitioner. IOP practitioners are trained to perform the role of both scientist and practitioner (Highhouse \& Schmitt, 2012). The 'scientist' dimension implies that IOPs generate knowledge through scientific investigation by means of applying scientific methods. The 'practitioner' dimension relates to the application of this knowledge to identify and solve specific work-related problems (Bergh, 2013; Van Vuuren, 2010). The psychological acts that IOPs may perform relate to specific science-practice domains stipulated by the HPCSA. These domains include recruitment and selection, training, vocational guidance, ergonomics, consumer behaviour and employee wellbeing (HPCSA, 2005). IOPs may also perform supportive 
psychological interventions and short-term therapeutic counselling interventions for the purposes of diagnosing and enhancing work-related adjustment challenges, and improving individual, group and organisational functioning (Department of Health, 2012). Furthermore, the roles of IOPs are influenced by the positions they employ within various organisational contexts. On the one hand, the IOPs may be employed internally by an organisation as practitioner or externally by a consulting firm (Moyo, 2012). On the other hand, IOPs may be employed in the scientific base of the profession as academics or researchers (Chamda, 2013; Lefkowitz, 2010). Consequently, the multiple roles that IOPs may perform could lead to ambiguity and role confusion.

Fourthly, the IOP practice domains are similar to areas of practice relating to other professions such as management practices, including HRM (Moyo, 2012). IOPs often perform activities that are similar to those of HRM practitioners. This has contributed to the confusion and on-going identity crises (Benjamin \& Louw-Potgieter, 2008; Schaerer, 2011; SIOPSA, 2010). To further clout the identity dilemma, a high percentage of IOPs are employed in HR positions (Moyo, 2012; Van Zyl et al., 2010). Van Zyl et al. (2013a) suggest that the ambiguity associated with the distinction between IOP and HRM may be attributed to the professional training which practitioners receive at a tertiary educational level. Although IOPs have academic knowledge in both psychology and business (Schreuder \& Coetzee, 2010), some tertiary institutions may emphasise the psychological domains of the profession, whilst others emphasise the business or HR related aspects (Van Tonder \& Roodt, 2008). This results in confusion in industry as various IOPs have different understandings of their roles, functions and duties based on the training which they received. As a result, the distinctiveness of IOP is threatened when presented at different faculties across tertiary institutions, such as HRM management (Ryan \& Ford, 2010; Venter \& Barkhuizen, 2005). In addition, competition amongst IOPs and other professionals over control of specific psychological acts (Venter \& Barkhuizen, 2005; Van Zyl, 2015) and the close alignment of job descriptions, tasks and functions between IOPs and HRM practitioners may contribute to an identity crisis within the IOP domain (Chamda, 2013).

Therefore, the literature shows that clarity relating to how IOP should be defined (conceptualised), the professional designation and/or title and/or label, the roles of the IOPs as well as the distinction from HRM needs to be established. A shared understanding from these factors between IOPs, registered intern-psychologists and student psychologists is integral to ensuring the survival of the profession within South Africa.

\section{Conceptualising industrial and organisational psychology within South Africa}

IOP as an applied subdiscipline of psychology (Coetzee \& Van Zyl, 2014) focuses on the scientific study of human behaviour within work-related contexts (Schreuder \& Coetzee, 2010; Van Vuuren, 2010). IOP is concerned with the development and application of psychological processes, practices and principles in work-related contexts (Bergh, 2009; Schreuder \& Coetzee, 2010) to the benefit of organisational functioning, performance and economic wellbeing (Bergh, 2013). With the aim of directly benefiting the economic well-being of the organisation, IOP is concerned with optimising individual, group and organisational wellbeing and effectiveness (Schreuder \& Coetzee, 2010) through scientific psychological processes. Practitioners in this field are trained within the science-practitioner model (Byrne et al., 2014; Coetzee \& Van Zyl, 2014a), where individuals act as scientists that facilitates the development of knowledge and evidence-based solutions in various IOP-related practice domains, such as career psychology, employee wellness and organisational development (Bergh, 2013; Schreuder \& Coetzee, 2010).

Within the South African context, individuals officially practicing as IOPs hold at least a master's degree in IOP and are required to undergo a 12-month professional internship and pass a formal board examination before being able to register as a psychologist with the HPCSA (Bergh, 2013). The work of IOPs in South Africa is governed by the HPCSA, which regulates the professional registration of IOPs and ensures that practitioners practice in areas in which they are professionally trained and illustrate competence (Coetzee \& Van Zyl, 2014a; Guest \& Kriek, 2008; Schreuder \& Coetzee, 2010). These practice areas are legislated domains (e.g. career psychology, psychometric assessments, personnel psychology, etc.) which inform the IOPs' scope of professional practice within South Africa (Van Zyl et al., 2010). However, the legislated scope of practice and professional practice does not provide clarity as to the roles, functions and value proposition of the South African IOPs. From the discussion above it is evident that contemporary theories of IOP are very broad and could describe any behavioural scientist, HRM practitioner, manager or consultant.

\section{Professional designation or label of industrial and organisational psychology}

The recurring identity crisis is fuelled by a lack of brand identity (Ryan, 2003) as a result of the various professional designations, titles or labels which are employed by registered IOP practitioners. Traditionally, IOP has not always been labelled IOP and is currently known by as many as 11 names: industrial psychology, organisational psychology, industrial-organisational psychology, work psychology, work and organisational psychology, organisational behaviour, organisation development, occupational psychology, occupational and/or organisational psychology, vocational psychology, and humanitarian work psychology (Olson-Buchanan, Bryan \& Thompson, 2013). The name of IOP furthermore differs across many countries and is 
currently labelled as occupational psychology (UK), work psychology (Europe), industrial-organisational psychology (USA) and organisational psychology (Australia) (Warr, 2007). In South Africa, practitioners and academics have been debating whether the name of IOP sufficiently addresses the needs of the environment (Guest \& Kriek, 2008) and different labels are used to refer to the total field of IOP today (Van Zyl et al., 2013b). A study conducted by Chamda (2013) found that there is no overall agreement regarding the name of the profession which remains a key challenge to the identity of the IOP profession. The variation in name often creates ambiguity and uncertainty as clients may not always be aware of what the profession entails (Strümpher, 2007; Van Zyl et al., 2013a). It is suggested that having a universal professional label might reduce the identity challenges faced by the IOP profession.

\section{Professional roles of the industrial and organisational psychologists}

The role of the IOPs generally includes assisting and supporting employees in the workplace (Moyo, 2012). Van Vuuren (2010) emphasised the role of scientist and indicated that IOPs contribute to the general knowledge base of psychology and applies that knowledge to identify and solve work-related problems. This is in accordance with the scientist-practitioner model (Muchinsky, 2003) which positions the IOPs as a scientist or as a practitioner. In contrast, Lefkowitz $(2005,2008)$ has pointed to deficiencies in the scientist-practitioner model and suggested a scientistpractitioner-humanist model with an emphasis on enhancing human welfare. Barnard and Fourie (2007) in their study identified six generic roles of IOPs: (1) scientist and/or researcher; (2) strategic partner; (3) enabler; (4) developer and/or counsellor; (5) watchdog; and (6) leader. These roles are furthermore comprised of many other roles, including an academic, change agent, coach, mentor and consultant. In a study conducted by Barkhuizen, Jorgensen, and Brink (2014) the role of IOPs as counsellor was also emphasised as an essential role requiring unique skills and competencies.

\section{Difference between human resource management and industrial and organisational psychology}

Maintaining the distinctiveness of IOP from HRM contributes to the on-going identity problem (Ryan \& Ford, 2010). Specifically within the South African context, various authors established a large degree of overlap and fusion between the two disciplines (Barnard \& Fourie, 2007). Benjamin and Louw-Potgieter (2008) established that IOPs typically perform general human resource work. According to these authors the only feature that set IOPs apart from HRM practitioners may include the training and registration requirements as set out in The Health Professions Act of South Africa. Schaerer (2011) found that apart from the use of behavioural science in the workplace, the work content of IOPs and HR managers may be very similar. Correspondingly,
Bartram and Roe (2005) found that the work content of the two professions are alike in terms of the work setting, coworkers, clients, purpose, objects, methods, and time frame for providing services to clients. According to Chamda (2013) ambiguity and role confusion is created by the close alignment of job descriptions and tasks due to the focus being on individuals and employees. From a legal perspective, the major designation between these two professions is the type of tools employed. IOPs are able to employ psychometric assessments, whereas HR managers are not legally permitted to administer, analyse, interpret or provide feedback on psychometric tests (Health Professions Act 56, 2010). Further, IOPs are currently permitted to engage forensic work whereas HRM practitioners aren't permitted to. However, the enormous overlap between the roles of IOPs and HRM practitioners may result in ambiguity and confusing professional boundaries, which may impact the identity of the IOP profession (Ryan, 2003).

\section{Aims of the study}

The aims of this study were as follows:

- To conceptualise IOP from a South African industrial psychologists' perspective;

- To explore how IOPs perceive their roles;

- To determine the preferred professional designation (or 'label') for IOP; and

- To differentiate between HRM and IOP from registered South African industrial psychologists' perspective.

\section{Method}

\section{Research design}

A post-positivistic (Zammito, 2004) qualitative content analytic (Duriau, Reger \& Pfarrer, 2007) and descriptive research design (Creswell, 2013; De Vos, Strydom, Fouche \& Delport, 2002) was employed in this study. Post-positivism is an interpretive qualitative framework which accepts that philosophies, theorems, objects, ideas and knowledge are developed as a result of the investigative process, where context is required to interpret, or 'process' the researched reality whilst adhering to the principles of scientific rigour (Van Zyl, 2013b).

\section{Research setting}

The study was conducted through presenting registered IOP's with an open-ended questionnaire by means of an electronic web-based questionnaire. The structured, openended web-based questionnaire format was employed to obtain participants' natural, spontaneous responses and to avoid the associative biases which may result from suggestive responses (Reja, Manfreda, Hlebec \& Vehovar, 2003). Research suggests that responses obtained through open-ended web-based questionnaires provides richer responses (Miller \& Lambert, 2014; Reja et al., 2003; Saris \& Gallhofer, 2014) although, it may be subject to increased levels of survey non-response (Saris \& Gallhofer, 2014). 
Further, the online research setting allows for the participant to engage with the questionnaire at his and/or her own time and pace, in an environment which is comfortable and convenient.

\section{Entrée and establishing researcher roles}

Potential participants were identified through the HPCSA database of registered IOPs. A web-based questionnaire was developed alongside a document explaining the purpose, objectives, and nature of the study and sent to the participants. This document highlighted the roles and responsibilities (e.g. confidentiality, informed consent, right to withdraw etc.) of all stakeholders (respondents and researchers) and explained the research procedure (i.e. expectations of participants, time associated with completion). Contact information for the researcher was provided, should participants have required further information or clarification.

\section{Sampling and participants}

A census-based sample $(n=151)$ of IOPs across South Africa $(N=1688)$ was drawn. Table 1 provides a detailed overview of the demographics of the sample. The majority of the respondents were married $(64,90 \%)$, Afrikaans speaking (58, $28 \%)$, white $(87,42 \%)$, females $(64,9 \%)$ between the ages of 30 and 39 years $(29,14 \%)$ with children $(60,26 \%)$. Further, the majority of the participants obtained their master's degree from the North-West University $(22,51 \%)$ and have been registered as psychologists between 1 and 5 years $(35,1 \%)$, with 115 respondents being employed by an organisation $(75,49 \%)$ as opposed to 34 participants being self-employed $(22,52 \%)$. These individuals were predominantly employed in a large organisation $(67,55 \%)$, mostly in non-managerial positions $(53,64 \%)$, whilst $22,52 \%$ are employed within the consulting industry.

\section{Data collection methods}

Participants completed an open-ended, electronic web-based questionnaire relating to their views of IOP as a profession (definition, roles and professional title of IOPs) as well as its differentiation from HRM. The questionnaire formed part of a larger study on the identity and well-being of IOPs within South Africa and contained sections relating to (1) personal demographics (e.g. age, gender, race, etc.), (2) professional demographics (e.g. years of registration, employment status), (3) self-report questionnaires (e.g. the mental health continuum) and (4) open-ended questions. The questionnaire was presented in English as it was assumed that individuals with a masters' degree in industrial psychology would be proficient in the language. The open-ended questionnaire contained to following questions:

- How do you define the profession of industrial and/or organisational psychology?

- How do you see the role of the I/O psychologist?

- If you had the opportunity, how would you 'label' the profession of psychology at work?

- What is the difference between HRM and IOP?
TABLE 1: Characteristics of the participants.

\begin{tabular}{|c|c|c|c|}
\hline Item & Category & Frequency & Percentage \\
\hline \multirow[t]{2}{*}{ Gender } & Male & 53 & 35.10 \\
\hline & Female & 98 & 64.90 \\
\hline \multirow[t]{4}{*}{ Race } & Black (African) & 8 & 5.30 \\
\hline & Coloured & 6 & 3.97 \\
\hline & Indian & 5 & 3.31 \\
\hline & White & 132 & 87.42 \\
\hline \multirow[t]{6}{*}{ Age } & $20-29$ years & 29 & 19.21 \\
\hline & $30-39$ years & 44 & 29.14 \\
\hline & $40-49$ years & 42 & 27.81 \\
\hline & $50-59$ years & 25 & 16.56 \\
\hline & $60-69$ years & 9 & 5.96 \\
\hline & $70+$ years & 2 & 1.32 \\
\hline \multirow[t]{7}{*}{ Language } & Afrikaans & 88 & 58.28 \\
\hline & English & 55 & 36.42 \\
\hline & Sepedi & 1 & 0.66 \\
\hline & Sestswana & 1 & 0.66 \\
\hline & IsiTsonga & 2 & 1.33 \\
\hline & isiXhosa & 3 & 1.99 \\
\hline & Other & 1 & 0.66 \\
\hline \multirow[t]{5}{*}{ Marital status } & Single & 34 & 22.52 \\
\hline & Married & 104 & 68.87 \\
\hline & Divorced & 7 & 4.64 \\
\hline & Widowed & 1 & 0.66 \\
\hline & Living together/life partner & 5 & 3.31 \\
\hline \multirow[t]{2}{*}{ Parental status } & With children & 91 & 60.26 \\
\hline & Without children & 60 & 39.74 \\
\hline \multirow{13}{*}{$\begin{array}{l}\text { University where Master's } \\
\text { degree was obtained }\end{array}$} & Stellenbosch University & 13 & 8.61 \\
\hline & University of Cape Town & 5 & 3.31 \\
\hline & $\begin{array}{l}\text { University of the } \\
\text { Witwatersrand }\end{array}$ & 8 & 5.30 \\
\hline & University of South Africa & 31 & 20.53 \\
\hline & University of Fort Hare & 1 & 0.66 \\
\hline & $\begin{array}{l}\text { University of the } \\
\text { Western Cape }\end{array}$ & 3 & 1.99 \\
\hline & $\begin{array}{l}\text { University of Johannesburg } \\
\text { (Formerly RAU) }\end{array}$ & 16 & 10.60 \\
\hline & University of Pretoria & 21 & 13.91 \\
\hline & University of KwaZulu-Natal & 5 & 3.31 \\
\hline & $\begin{array}{l}\text { North-West University } \\
\text { (Formerly PU-CHO) }\end{array}$ & 34 & 22.51 \\
\hline & University of the Free State & 4 & 2.65 \\
\hline & Other & 9 & 5.96 \\
\hline & Missing value & 1 & 0.66 \\
\hline \multirow{10}{*}{$\begin{array}{l}\text { Years registered as an I/O } \\
\text { psychologist }\end{array}$} & 0 & 12 & 7.95 \\
\hline & $1-5$ years & 53 & 35.10 \\
\hline & $6-10$ years & 32 & 21.19 \\
\hline & $11-15$ years & 18 & 11.92 \\
\hline & $16-20$ years & 18 & 11.92 \\
\hline & $21-25$ years & 8 & 5.30 \\
\hline & $26-30$ years & 5 & 3.31 \\
\hline & $31-35$ years & 3 & 1.99 \\
\hline & $36-40$ years & 1 & 0.66 \\
\hline & $40+$ years & 1 & 0.66 \\
\hline \multirow[t]{3}{*}{ Employment status } & Self-employed & 34 & 22.52 \\
\hline & Employed by an organisation & 114 & 75.49 \\
\hline & Other & 3 & 1.99 \\
\hline \multirow[t]{5}{*}{ Type of organisation } & $\begin{array}{l}\text { Micro business ( } 1-5 \\
\text { employees) }\end{array}$ & 30 & 19.87 \\
\hline & $\begin{array}{l}\text { Small business }(6-50 \\
\text { employees }\end{array}$ & 9 & 5.96 \\
\hline & $\begin{array}{l}\text { Medium business (51-120 } \\
\text { employees) }\end{array}$ & 7 & 4.64 \\
\hline & $\begin{array}{l}\text { Large business (121+ } \\
\text { employees) }\end{array}$ & 102 & 67.55 \\
\hline & NGO & 3 & 1.98 \\
\hline
\end{tabular}


TABLE 1: (Continues...) Characteristics of the participants.

\begin{tabular}{llcc}
\hline Item & Category & Frequency & Percentage \\
\hline Type of position & Managerial position & 70 & 46.36 \\
& Non-managerial position & 81 & 53.64 \\
Type of industry & Agriculture & 2 & 1.32 \\
& Education & 31 & 20.53 \\
& Across industries (various) & 6 & 3.98 \\
Automotive/transport/ & 4 & 2.65 \\
logistics & & \\
Banking/finance & 14 & 9.27 \\
Consulting & 34 & 22.52 \\
Construction/engineering & 5 & 3.31 \\
& Defence & 1 & 0.66 \\
Energy/chemicals & 6 & 3.97 \\
FMcG/retail \& wholesale & 8 & 5.30 \\
Government & 6 & 3.97 \\
& Health & 2 & 1.32 \\
Human resources technology & 4 & 2.65 \\
(IT) & & \\
Legal & 1 & 0.66 \\
Media/entertainment/ & 3 & 1.99 \\
hospitality & & \\
Mining & 6 & 3.98 \\
Manufacturing & 5 & 3.31 \\
Telecommunications & 3 & 1.99 \\
Other & 6.62 \\
\hline
\end{tabular}

\section{Data recording}

The questionnaire was uploaded to LimeSurvey ${ }^{\mathrm{TM}}$ and piloted with a small group of IOPs. Upon submission of each section, the survey was automatically saved on the distribution server. The data was securely submitted through a Secure Sockets Layer (SSL) connection to the server and the data was saved in a Structured Query Language (SQL) database for later retrieval. Cookies to the server were disabled, and Internet Protocol (IP) Addresses were automatically removed to ensure anonymity of participants. The data was then downloaded into a Microsoft Excel ${ }^{\circledR}$ spreadsheet for further processing.

\section{Strategies employed to ensure data quality and integrity}

Creswell (2013) argued that the quality and integrity of the data should be ensured through a clearly established research objective and appropriate data analysis and/or collections methods. The methods employed to ensure integrity and quality data was guided by the provisions of (1) credibility, (2) trustworthiness, (3) transferability and (4) conformability (Coetzee \& Van Zyl, 2014a).

Firstly, the questionnaire and research questions were developed and submitted to nine senior professors in the field of IOP for input. Secondly, the questionnaire was finalised and a pilot study of the questionnaire was launched. The questionnaire was administered to a small group of IOPs within Gauteng $(n=8)$ in order to determine the credibility and trustworthiness of the questionnaire and the obtained data. Thirdly, the questionnaire was uploaded to a server with SSL and SQL capabilities in order to ensure that data was obtained and stored securely. This was done to illuminate the possibility of survey bots, spam bots and hackers affecting the quality of the responses. Fourthly, a coding taxonomy was developed amongst the researchers in order to ensure consistency and conformity. Fifthly, Coetzee and Van Zyl (2014a) suggested that open communication between the research team continued through the analysis and coding process to address potential problems relating to the analysis. Sixthly, where disagreements relating to coding consistency and interpretation occurred, expert opinions were sought to resolve disputes by the research team (Van Coetzee \& Van Zyl, 2014a). Seventhly, there was approximately $90 \%$ overlap between the researchers relating to the coding process, which is $20 \%$ higher than the suggested average percentage of agreement overlap of Miles and Huberman (1994). Finally, all the data has been stored for future scrutiny.

\section{Data analysis procedure}

The data was downloaded in Microsoft Excel format and was processed through the use of content analysis (Creswell, 2013). Content analysis provides for the analysis of large amounts of 'mute' textual information to systematically identify or locate important properties of its content through structured categorisation (Creswell, 2013; Van Zyl, 2013b). This design is considered non-intrusive (Duriau et al., 2007) and highly flexible (Creswell, 2013), and the results can be replicated (Van Zyl, 2013b). Although, content analysis is still subjected to the limitations associated with traditional nominal-oriented measurement techniques (Salkind, 2012). The best practice guidelines outlined for content analyses were utilised in order to analyse the data and to determine primary themes (Chaichanasakul et al., 2011; Petticrew \& Roberts, 2006; Whiston, Rose, Peterson \& Nguyen, 2013).

Firstly, the data were cleaned through removing responses that were partial, or that contained irrelevant information (such as '....' 'don't care' 'DFSSDADSAGdsgasd' or blank responses, etc.). Secondly, a thorough overview of the data was compiled whereby the researchers read through the information to obtain a 'general feel for the data' (Creswell, 2013). Thirdly, primary themes were derived through clustering similar responses together by means of coding. Fourthly, the coding process was underpinned by co-coding whereby the primary researchers coded the data individually and (in)congruencies were discussed to establish the final themes.

\section{Results}

The findings of this study are presented in four sections. Firstly, an overview of the results associated with the definition of IOP is presented. Secondly, the themes associated with the self-perceived roles of the IOPs are highlighted. Thirdly, the professional designations (title or 'label') for the profession are highlighted. Finally, IOPs' perceptions associated with the difference between human resources and IOP are presented.

\section{Definition of the profession of industrial and organisational psychology}

Table 2 provides an overview of the findings which emerged from the question associated with the definition of IOP. The 
findings produced 12 congruent themes which imply a relatively shared conceptual definition for IOP amongst the participants.

Most participants believed that IOP involved 'optimising individual, group, organisational and societal potential to improve performance/productivity and sustainability' through 'applying processes, methods, paradigms and principles of psychology at work'. A core theme associated with the conceptualisation of IOP within the South African context related to the 'facilitation of well-being and general health' through 'working with people at work'. Participants also argued that IOPs are 'specialists in human behaviour' that 'develops scientific theories' relating to the world of work. Further, it also involved a function relating to the 'integration of individuals into the world of work' and facilitating the 'enhancement of human resource policies and practices'. It was also indicated that IOP relates to the 'diagnosis of problems within an organisation' and 'involves a professional registration with a professional body'. Finally, only one participant indicated that ethical behaviour forms part of IOP's conceptualisation. One participant indicated that he and/or she was unsure as to how IOP should be defined.

\section{The role of industrial and organisational psychologists}

Flowing from the conceptualisation of IOP emerges the selfperceived roles of the industrial psychologist. Themes associated with the role of the IOPs within South Africa which emerged from the data are presented in Table 3.

The findings indicated that the IOPs fulfil various roles within the organisational context. The majority of

TABLE 2: Definition of IOP.

\begin{tabular}{|c|c|c|}
\hline Theme & $f$ & Response \\
\hline $\begin{array}{l}\text { Optimising individual, group, organisational and societal potential to improve } \\
\text { performance and/or productivity and sustainability }\end{array}$ & 64 & $\begin{array}{l}\text { 'Maximising an organisation functioning by optimising an employee's role, both } \\
\text { in an individual and group setting' }\end{array}$ \\
\hline Applying processes, methods, paradigms and principles of psychology at work & 46 & 'Application of psychological theory in the workplace' \\
\hline Facilitating well-being and general health & 38 & $\begin{array}{l}\text { 'The profession of IOP is there to help other people to manage their well-being } \\
\text { to enable them to follow the career path that they are interested in' }\end{array}$ \\
\hline Specialising in human behaviour & 24 & $\begin{array}{l}\text { 'Behavioural specialists assisting with greater work achievements for individuals, } \\
\text { teams and organisations' }\end{array}$ \\
\hline Developing scientific theories & 18 & $\begin{array}{l}\text { 'Developing scientific theories and models to enhance leadership, group } \\
\text { effectiveness and organisation effectiveness' }\end{array}$ \\
\hline Integrating individuals in the world of work & 13 & $\begin{array}{l}\text { 'This profession is the basis for the integration of employees in the world of } \\
\text { work' }\end{array}$ \\
\hline Work with people at work & 6 & $\begin{array}{l}\text { 'Working with individuals and groups to ensure personal and professional } \\
\text { growth in a work context' }\end{array}$ \\
\hline Enhancing HRM policies and practices & 4 & $\begin{array}{l}\text { 'I/O psychology is a profession that enhances HR practice by way of research and } \\
\text { science based practice' }\end{array}$ \\
\hline Professional registration & 3 & 'Professionally registered with the HPCSA' \\
\hline Not sure & 1 & 'I am not sure' \\
\hline Diagnosing organisational problems & 1 & 'Diagnosing and fixing those areas that are not well' \\
\hline
\end{tabular}

$f$, Frequency.

TABLE 3: The role of industrial psychologists.

\begin{tabular}{|c|c|c|}
\hline Theme & $f$ & Response \\
\hline Wellness facilitator & 36 & 'The role of the IOP psychologist is a psychologist to individuals and organisations on their employee wellness' \\
\hline People development & 26 & 'Developing and leading the Human Capital in the organisation' \\
\hline Organisational developmental role & 26 & 'Development of organisations in which human beings can flourish' \\
\hline Scientist - practitioner & 23 & $\begin{array}{l}\text { 'As a professional scientific contributor, and psychologist who specialises in behavioural, group- and organisational issues. A } \\
\text { science-practitioner' }\end{array}$ \\
\hline Facilitator/advisor/consultant & 25 & 'A facilitator of understanding, effectiveness and improvement' \\
\hline Business partner & 20 & 'Strategic business partner' \\
\hline Behavioural specialist & 20 & 'Behavioural specialists assisting with greater work achievements for individuals, teams and organisations' \\
\hline Strategist & 15 & $\begin{array}{l}\text { The strategist on organisational and employee behaviour the person who strategically and pro-actively must predict } \\
\text { behaviour and facilitate understanding and growth }\end{array}$ \\
\hline Change agent & 12 & 'A change agent, with sound analytical and organisational skills - but it depends on the competence of the IO psychologist' \\
\hline Counsellor, therapist, mentor and coach & 9 & $\begin{array}{l}\text { The role of the IOP psychologist is a psychologist/therapist/coach/mentor to individuals and organisations on their } \\
\text { performances, and choices of jobs/careers }\end{array}$ \\
\hline Interventionist & 7 & To develop and facilitate [organisational] interventions' \\
\hline Diagnostic & 5 & 'Diagnosing problems within the organisation' \\
\hline Psychometrics and assessment & 4 & 'I often get the feeling that it is only seen as Psychometrics by the Academics and SIOPSA/HPCSA - how limiting!!!!' \\
\hline Enhancing HRM processes & 4 & 'The profession is there to guide general HR practitioners on best practice and ethics' \\
\hline Managerial role & 3 & 'To be part of the senior management team and to drive the strategy of the company' \\
\hline Career developers and counsellors & 3 & $\begin{array}{l}\text { 'Developing and implementing interventions and guidance from school leavers throughout career advancement process, } \\
\text { including retirement and retrenchment planning' }\end{array}$ \\
\hline
\end{tabular}

$f$, Frequency. 
the individuals indicated that the primary role of the IOPs is that of a wellness facilitator, focusing on enhancing the overall well-being and general health of individuals within the organisation. Similarly, the IOPs fulfil a people development role which implies the optimal development of individuals and groups through adopting the role as counsellor, therapist, mentor and coach. Similarly, the participants indicated that another core role is associated with organisational development, which relates to assisting the organisation to grow and develop in order to enhance performance and productivity. This could be done through adopting a facilitator and/or advisor and/or consultant, strategist or change agent role. As a science-practitioner, the IOPs should be seen as behavioural specialists that can scientifically predict human behaviour of individuals, groups and teams within organisational contexts. Further, the IOPs function as business partners, usually within a managerial role, who aids in the alignment of strategic business objectives with employees (both management and subordinates) within organisational contexts. As such, the IOPs may adopt the role to enhance HR policies and practices. Similarly, the IOPs adopt a diagnostic and interventionist role in order to determine the root cause of problems within the organisation and design appropriate interventions to address these problems. They engage in psychometrics and assessments as part of their primary roles and acts as the watchdog and custodian of ethics within the organisation. Finally, they act as career developers and counsellors in order to facilitate individuals through the various career phases.

\section{Professional designation or label for industrial and organisational psychology}

The professional designations or labels for IOP as presented by the participants are summarised in Table 4 . The majority of the participants indicated that work psychology was deemed to be a more fitting professional designation than the traditional IOP.

\section{Differences between human resource management and industrial and organisational psychology}

Finally, the perceptual differences between HRM and IOP of registered industrial psychologists are presented in Table 5.

From the data it is evident that human resources main' functions are administrative and process driven, involve transactional and operational functions and ensure compliance to processes and policies (governance). Further, human resources are perceived as being generalists with managerial functions who implement the strategies developed by the IOPs within an organisation.

In contrast, the IOPs are positioned in a conceptual or strategic, behavioural specialist role where his and/or her main functions are associated with the development of psychological strategies, systems, theories and methodologies to enhance individual, group and organisational performance. The IOPs also differ from HRM in relation to their focus on developing individuals and organisations $(f=19)$.

\section{Discussion}

The purpose of this study was to explore the professional identity of IOPs within the South African context. Specifically, the aim was to conceptualise IOP, determine the professional designations of IOPs and to determine the roles which they perform within the South Africa context. Further, the aim was to investigate the difference between HRM and IOP as perceived by registered industrial psychologists within South Africa. The findings indicated that IOPs within South Africa predominantly share a congruent definition of IOP, with some difference in approach and application. However, there seems to be incongruence associated with the roles and professional designations amongst IOPs within this context. Finally, the results indicated a clear theoretical distinction between HRM and IOP as perceived by IOPs within South Africa.
TABLE 4: Professional designation or label for IOP.

\begin{tabular}{l} 
Theme \\
Work psychology \\
Coaching and consulting psychology \\
Business psychology \\
Industrial psychology \\
Vocational psychology \\
Human capital psychology \\
Optimisation specialists \\
Human resources \\
Behavioural specialist \\
Performance psychology \\
Transformation engineering \\
Business decision architect \\
People developer \\
Occupational psychology \\
Wellness enhancer \\
\hline , Frequency.
\end{tabular}

Response
'Work psychologists'
'Industrial/Organisational Psychology to be in touch with international trends'
'Organisational Coaching or Consulting Psychologist'
'Business Psychologist - applying scientific methods to business solutions from a
framework of understanding human behaviour'
'Just industrial psychology'
'Vocational psychology'
'Human Capital Psychologists'
'Optimisations specialists'
'Human resource managers'
'Behavioural specialist'
'Performance psychology'
'People and transformation engineering'
'Business decision architect'
'People development'
'Occupational psychologists'
'Wellness enhancer'


TABLE 5: Differences between HRM and IOP.

\begin{tabular}{|c|c|c|c|}
\hline Human resources & $f$ & IOP & $f$ \\
\hline Administrative and process driven & 44 & Developing psychological strategies, systems, theories and methodologies & 49 \\
\hline Transactional and operational functions & 44 & Conceptual/strategic role & 28 \\
\hline Ensures compliance to policies and procedures (governance) & 36 & Behavioural specialist & 28 \\
\hline Generalists and managerial functions & 15 & Focus on enhancing individual and/or organisational performance & 20 \\
\hline Implementing IOP strategies & 15 & Developing people and organisations & 19 \\
\hline Recruitment, selection and placement & 12 & Focuses on employee well-being & 11 \\
\hline Organisational support service & 6 & Transformational role & 11 \\
\hline Labour relations & 3 & Develops psychological interventions & 10 \\
\hline Career management & 2 & Diagnostic functions & 10 \\
\hline- & - & Psychometric assessments & 6 \\
\hline- & - & Research & 6 \\
\hline- & - & Change management & 5 \\
\hline- & - & Professionally registered with the HPCSA & 5 \\
\hline- & - & Counsellors & 2 \\
\hline- & - & Forensic work & 2 \\
\hline- & - & Better qualification than HRM & 1 \\
\hline- & - & Ergonomics & 1 \\
\hline- & - & Problem solving & 1 \\
\hline- & - & Systems thinking & 1 \\
\hline
\end{tabular}

$f$, Frequency.

\section{Conceptualising industrial and organisational psychology within South Africa}

The first objective of the study related to conceptualising IOP from a South African industrial psychologists' perspective. Our results indicated that IOP could be conceptually defined as: Both a discipline and a profession which relates to optimising individual, group, organisational and societal potential through developing or applying scientific theories, processes, methods, paradigms and principles of psychology at work in order to facilitate sustainable improvements in performance, productivity, well-being and general health. It is a specialised field of professional practice aimed at diagnosing, understanding, predicting and managing human behaviour within work contexts. It has to do with working with people, their integration into the world of work through enhancing human resource processes and practices in an ethical manner. Although elements of this conceptualisation are in line with those proposed by traditional (Benjamin, 2005; Van Tonder \& Roodt, 2008; Van Zyl et al., 2010) and contemporary authors (Aamodt, 2015), it differs in relation to the focus and scope of the discipline and/or profession.

The findings suggest that IOP's target audience has evolved from the traditional organisationally centred focus (individual and/or group and/or organisational view), towards an integrated, holistic (societal and/or community) perspective (Coetzee \& Van Zyl, 2014b; Page, 2015). Given the predominant collectivistic culture within South Africa (Crafford, Adams, Saayman \& Vinkenburg, 2015), IOPs may positively influence the performance of individuals with organisations through focusing interventions on the adjourning communities or society where employees' families function (Eaton \& Louw, 2000). This is in line with post-modern approaches towards systems thinking aimed at enhancing individual, and group performance within collectivistic social orientations (Aamodt, 2015).
Similarly, in contrast to both Benjamin (2005) and Van Zyl et al. (2010), the findings suggest that the IOP may have adopted a positive psychological, performance based scope. From this perspective, the focus seems to be on optimising individual, group and organisational performance, in contrast to solely focusing on what is proverbially 'wrong' within that context. Here strengths-based perspectives and approaches are highlighted, which supports the findings of Coetzee and Van Zyl (2014a) as well as Rothmann and Cooper (2015). As such, industrial psychology can be conceptualised as optimising the potential of individuals, groups, organisations and the community by implementing scientific processes with individual and organisational performance and wellness as outcomes, ensuring organisational sustainability (Rothmann \& Cooper, 2015).

\section{Contemporary roles of the organisational psychologist}

The second objective of the study related to the way IOPs perceive their work-roles. The majority of the participants indicated that the primary role of the IOPs is that of wellness facilitators. The traditional boundaries or scope of practice of the IOPs have expanded beyond the constraints of the organisation (Barkhuizen, Jorgensen \& Brink, 2015), whereby the focus is on enhancing the overall level of personal wellbeing of an employee in order to address or prevent workplace problems. The IOPs as wellness facilitators may be tasked with the development, implementation and evaluation of employee assistance programmes or interventions aimed at assisting employees with personal and/or professional problems ranging from managing HIV and/or AIDS and burnout to facilitating optimal personal growth (Barkhuizen et al., 2015).

The people developer role which the IOPs may portray relates to the facilitation of optimal development of individuals and 
groups, supported by the counsellor, therapist, mentor and coach role. Here, the focus is on the personal and/or professional developmental needs of the individuals, as well as the function and/or role managing talent (Jorgensen, Van Zyl \& Stander, 2016; Van Zyl \& Stander, 2013). Not only is people development an integral part of talent management strategies, but also core to interventions associated with engaging and retaining talented people (Van Zyl \& Stander, 2013). As such, this role encompasses the development and implementation of human potential development strategies aimed at the optimisation of individual, team and organisational strengths. In this context, the IOPs could adopt a strategic supportive, facilitating role, whereby the individual (or team) is guided and/or coached through a process of self-discovery and growth. Although not prominent within this project, within the broader people development role, the IOPs could also act as career developers and/or counsellors as an approach to aid professional development.

Flowing from the people development role, IOPs may also adopt an organisational developer role and change agent role. This role relates to processes and mechanisms that are implemented to facilitate organisational growth and development aimed at establishing sustainable performance (Rothmann \& Cooper, 2015) as well as the management of the associative change process (Van Tonder \& Roodt, 2008). Attributable to constant change within the global market, organisational transformation, innovation and development is a continuous process which requires active management. The IOPs could adopt various roles in the organisational development and change management process, however the focus pertains to the linkage of individual preferences and/ or needs and/or strengths to organisational goals and/or objectives through a process of psychological re-engineering. As such, the IOPs could be tasked to diagnose organisational problems, influence organisational systems (processes and/ or policies) and - culture and/or climate, in order to develop strategies to enhance organisational capabilities (Rothmann \& Cooper, 2015; Van Tonder \& Roodt, 2008).

The facilitator and/or advisor and/or consultant role as well as the behavioural specialist role is aimed at acting as an independent specialist in understanding, predicting and influencing human behaviour within organisational contexts. Here, the IOPs could act as an objective soundboard to the organisation, with specialised knowledge and/or expertise in human behaviour, with the aims of enhancing individual, team or organisational performance. In this role, particular attention is paid to human behavioural dynamics within the organisational eco-system in order to (1) develop hypothesis and potential solutions to complex problems, (2) to present findings and recommendations, (3) to support the execution of difficult interventions, and (4) to manage human dynamics in the process (Koppes, 2014).

Furthermore, the IOPs act as science-practitioners and organisational strategists. In these roles the focus pertains to the development, implementation and evaluation op psychological acts (e.g. psychometric instruments; coaching processes, etc.) that are valid, reliable, credible and transferable. The IOPs develop psychological processes and strategies based on the scientific-method, in order to enhance the success of the intervention. Further, he and/or she focuses on scientifically predicting individual, group and team behaviour within organisational contexts. As a strategist, the IOPs aid in the development of a roadmap or blueprint to aid the organisation in expanding their performance foot print (Koppes, 2014) through linking human dynamics, to organisational systems (Aamodt, 2015). As such, the IOPs could act as valuable business partners and confidants of the executives within the organisation in the future.

However, in contrast to previous research within the South African context (see Benjamin \& Louw-Potgieter, 2008; Van Vuuren, 2010; Van Zyl et al., 2010), the IOPs may be less likely to want to engage in managerial roles or those associated with psychometric assessments, acting as watchdogs or custodians of ethics. This may be as a result of the change in scope and focus of traditional IOP work, as psychometrists are in an abundance within the South Africa context. IOPs are less likely to engage in the actual assessment process, but may function in a quality assurance and strategic role in this regard. Finally, they may be less likely to engage in activities associated with the enhancement of HR processes and practices as a primary role.

\section{Professional designations for industrial and organisational psychology}

The third objective of the study was to determine the preferred professional designation (or 'label') for the IOP by practitioners. Although majority of the participants indicated that work psychology is a more fitting professional designation than the traditional IOPs, the wide variety of labels obtained in this study suggest the support the importance of this research. The concept of work psychology seems more appropriate within the South African context given the nature of the roles and associative tasks of the registered IOPs. The move away from IOP as a professional designation may relate to the historical definition attached to the word 'industrial' which stems from the industrial revolution. Furthermore, it is important to note that out of the 151 individuals who participated in this research project, less than a third completed $(n=43)$ this section. This may be left open to interpretation for the reader. As such, the vast differences in labels as well as the small response rate, indicates that the professional designation of the IOPs needs further investigation.

\section{Differentiation between human resources and industrial and organisational psychology}

The final objective of the study was to differentiate between HRM and IOP from a registered South African industrial psychologists' perspective. The IOPs are positioned as conceptual or strategic, behavioural specialists with the main focus on the development of psychological strategies, systems, 
theories and methodologies to enhance individual, group and organisational performance, whilst HRM is observed as administrative, processes driven, transactional with an operational function to ensure compliance to policies and procedures. There is a clear distinction between a more dynamic, proactive approach (IOP) compared to the more transactional approach embodied by HRM. This is consistent with previous findings relating to the South African IOPs' perspectives relating to the differentiation (see Benjamin, 2005; Moyo, 2012). However, the findings are somewhat in contrast to international research relating to the roles and functions of HRM (Armstrong \& Taylor, 2014). Lussier and Hendon (2015) indicates that HRMs act in strategic or conceptual roles as the intended focus is on enhancing individual and organisational performance through aligning organisational strategies with human resources. Furthermore, HRM may also focus on employee well-being, and develop people within organisational roles (Armstrong \& Taylor, 2014). Although not permitted in South Africa, human resource practitioners within the global market also utilises psychometric assessment measures as part of their recruitment practices without being 'registered' as psychologists (Berman, Bowman, West \& Van Wart, 2015). Similarly, within the South African context, HRM also employs assessment centres, competency based assessments, behavioural observation and the like, to select best-fitting candidates. Albeit not psychometric in nature, this implies that they are also able to engage in similar assessment practices as IOPs. Therefore, one must be very cautious when dealing with these results as it is a one sided opinion.

\section{Limitations and recommendations}

This study was also presented with various limitations. The relatively small sample that completed the questionnaire is a definite limitation. The respondents are more representative of younger psychologist with 56\% registered for less than 10 years. This can be an indication that the 'more experienced' IOPs feel that this is a well debated topic and they don't want to make further contributions, or it is a case that the younger group are more willing and eager to clarify the identity. Similarly, the results may have been skewed relating to viewing the industrial psychologist as a wellness facilitator. The majority of the participants completed their master's degrees at the NWU $(22,51 \%)$; a tertiary education institution known for its 'wellness and well-being' focus. This may have influenced the results. It is suggested that future research aim to draw a representative sample of IOPs from the various tertiary education institutions in order to reflect the current reality more accurately.

Further, it is recommended that the HPCSA follow the same process that the South African Board for People Practices (SABPP) followed to clarify roles, competencies and outcomes for setting professionalstandards for industrial-organisational psychology. Comparing these standards with that of the HRM profession will clarify the overlap and vagueness between the two professions. This can lead to national standards (aligned with international standards) that universities can apply in designing their programs. This should address most of the challenges identified in this research. By identifying the national standards there need to be one, clear, general definition of the profession. From this the professional distinction, title or label should be clarified. If all universities train their students to achieve the same outcomes and focus on the same practice domains industry, the community and academia will have a clear picture of what to expect from the profession or its members. This information should enable the HPCSA to improve the audit process for training institutions.

Some people may reason that this will limit universities competitive advantage. However, these authors are of the opinion that universities need to focus their competitive advantage and value-add on their way of delivering the content to get to the standards. We firmly belief that there must be at least certain minimum standards and outcomes that need to be met by all training institutions. SIOPSA should then, as SAICA for the accounting profession, play a strong governing, marketing and alignment role. It should be interesting to compare and benchmark universities curricula against the result of this research.

\section{Conclusion}

Although this research adds value to the academia and practitioners, this will definitely not be the last debate on the issues surrounding IOPs' professional identity. Professional identity development should be seen as a dynamically fluid process, which evolves over time in order to ensure the relevance of both the IOP discipline and profession. Future processes to involve a wider audience and in depth discussion with all stake holders will be needed. This research underlines the important role that the IOPs play in individual and organisational performance and wellness. It can be expected that the role will become even more important in enhancing employee and organisational effectiveness.

\section{Acknowledgements Competing interests}

The authors declare that they have no financial or personal relationships which may have inappropriately influenced them in writing this article.

\section{Authors' contributions}

All authors contributed equally to the research project and this paper.

\section{References}

Aamodt, M.G. (2015). Industrial/organizational psychology: An applied approach (8th edn.). London, UK: Cengage Learning.

Aguinis, H., Bradley, K.J., \& Brodersen, A. (2014). Industrial-organizational psychologists in business schools: Brain drain or eye opener? Industrial and Organizational Psychology, 7(3), 284-303. http://dx.doi.org/10.1111/iops.12151

Armstrong, M., \& Taylor, S. (2014). Armstrong's handbook of human resource management practice. London, UK: Kogan Page Publishers. 
Avedon, M., \& Grabow, K. (2010). Professional identity: Organizational psychologists as chief human resource executives, Industrial and Organizational Psychology 3(3), 266-268. http://dx.doi.org/10.1111/j.1754-9434.2010.01236.x

Barkhuizen, H., Jorgensen, L.I., \& Brink, L. (2014). Exploring the role of the industrialorganizational psychologist as counsellor. South African Journal of Industrial Psychology, 40(1), Art. \#1193, 1-11.

Barkhuizen, H., Jorgensen, L.I., \& Brink, L. (2015). Training the industrial and organisational psychologist as counsellor: Are we doing enough? Acta Commercii, 15(1), 1-12. http://dx.doi.org/10.4102/ac.v15i1.253

Barnard, G., \& Fourie, L. (2007). Exploring the roles and contributions of industria psychologists in South Africa against a multi-dimensional conceptual framework (Part 2). South African Journal of Industrial Psychology, 33(2), 45-53. http://dx. doi.org/10.4102/sajip.v33i2.376

Bartram, D., \& Roe, A. (2005). Definition and assessment of competences in the context of the European diploma in psychology. European Psychologists, 10(2), 93-102. http://dx.doi.org/10.1027/1016-9040.10.2.93

Benjamin, J. (2005). Professional work and actual work: The case of industrial psychologists in South Africa. Unpublished masters dissertation, University of Cape Town, South Africa.

Benjamin, J., \& Louw-Potgieter, J. (2008). Professional work and actual work: The case of $1 / O$ psychologists in South Africa. South African Journal of Psychology, 38(1), 116-135. http://dx.doi.org/10.1177/008124630803800107

Bergh, Z.C. (2009). Fields of study and practice areas in industrial and organisational psychology. In Z.C. Bergh \& A.L. Theron (Eds.), Psychology in the work context (pp. psychology. In Z.C. Bergh \& A.L. Theron (Eds.),

Bergh, Z.C. (2013). Fields of study and practice areas in IOP. In Z.C. Bergh \& D.J. Geldenhuys (Eds.), Psychology in the work context (5th edn., pp. 9-19). Cape Town: Oxford University Press.

Berman, E.M., Bowman, J.S., West, J.P., \& Van Wart, M.R. (2015). Human resource management in public service: Paradoxes, processes, and problems. Newbury Park, CA: Sage.

Byrne, Z.S., Hayes, T.L., Mort, M.S., Hakel, M.D., Cortina, J.M., \& McHenry, J.J. (2014). Educating industrial-organizational psychologists for science and practice: Where do we go from here? Industrial and Organizational Psychology, 7(1), 2-14. http:// dx.doi.org/10.1111/iops.12095

Campana, K. (2014). Industrial and organizational psychology and community service involvement: Students helping locally. In W. Reichman (Ed.), Industrial and Organizational Psychology Help the Vulnerable (pp. 243-257)., London, UK: Palgrave Macmillan.

Chaichanasakul, A., He, Y., Chen, H., Allen, G.E.K., Khairallah, T.S., \& Ramos, K. (2011) Journal of career development: A 36-year content analysis (1972-2007). Journa of Career Development, 38(6), 440-455. http://dx.doi.org/10.1177/08948 45310380223

Chamda, N. (2013). Towards constructing the identity of industrial and organisational psychology. Unpublished masters dissertation, University of Johannesburg, South Africa.

Coetzee, M., \& Van Zyl, L.E. (2014a). A review of a decade's scholarly publications (2004-2013) in the South African journal of industrial psychology. SA Journal of Industrial Psychology, 4O(1), 1-16. http://dx.doi.org/10.4102/sajip.v40i1.1227

Coetzee, M., \& Van Zyl, L.E. (2014b). South African journal of industrial psychology: Annual editorial overview 2014: Editorial. SA Journal of Industrial Psychology 40(1), 1-5.

Cohen-Scali, V. (2003). The influence of family, social, and work socialization on the construction of professional identity of young adults. Journal of Career Development, 29(4), 237-249. http://dx.doi.org/10.1177/089484530302900402

Cooper-Thomas, H.D., \& Wright, S. (2008). Industrial-organisational psychology in New Zealand: Who are we and where are we going? The Australian and New Zealand Journal of Organisational Psychology, 1, 12-21. http://dx.doi. org/10.1375/ajop.1.1.12

Crafford, A., Adams, B.G., Saayman, T., \& Vinkenburg, C. (2015). The process of identity work: Negotiating a work identity. In P. W. Jansen \& G. Roodt (Eds.) Conceptualising and measuring work identity (pp. 53-86). Utrecht: Netherlands: Springer.

Creswell, J.W. (2013). Qualitative inquiry \& research design: Choosing among the five approaches. Thousand Oaks, CA: Sage.

Department of Health. (2012). Health Professions Act, 1974: Draft discussion document. Regulations defining the scope of the profession of psychology. Government Gazette, 16 July 2012. Pretoria, South Africa: Government Printer.

De Vos, A.S., Strydom, H., Fouche, C.B., \& Delport, C.S.L. (2002). Research at grass roots. For the social sciences and human service professions. Pretoria: Van Schaik.

Dobrow, S.R., \& Higgins, M.C. (2005). Developmental networks and professional identity: A longitudinal study. Career Development International, 10, 567-583. http://dx.doi.org/10.1108/13620430510620629

Duriau, V.J., Reger, R.K., \& Pfarrer, M.D. (2007). A content analysis of the content analysis literature in organization studies: Research themes, data sources, and methodological refinements. Organizational Research Methods, 10, 5-34. http:// dx.doi.org/10.1177/1094428106289252

Eaton, L., \& Louw, J. (2000). Culture and self in South Africa: Individualism-collectivism predictions. The Journal of Social Psychology, 140(2), 210-217. http://dx.doi. org/10.1080/00224540009600461

Guest, F., \& Kriek, H. (2008). Industrial and organizational psychology in South Africa. The Industrial-Organizational Psychologist, 46(2), 60-66.

Health Professions Council of South Africa (HPCSA). (2005). Scope of practice for psychology. Retrieved January 18, 2016, from http://www.hpcsa.co.za
Highhouse, S., \& Schmitt, N.W. (2012). A snapshot in time: Industrial-organizational psychology today. In I.B. Weiner, N.W. Schmitt, \& S. Highhouse (Eds.), Handbook of psychology, industrial and organizational psychology (2nd edn., pp. 3-13). psychology, industrial
Hoboken, NJ: Wiley.

ex, S.M., \& Britt, T.W. (2014). Organizational psychology: A scientist-practitioner approach. Hoboken, NJ: Wiley.

Jorgensen, L.I., Van Zyl, L.E., \& Stander, M.W. (2016). Training emerging psychologists as multi-cultural contextual coaches. In L.E. Van Zyl, M.W. Stander, \& A. Odendaal (Eds.), Coaching psychology: Meta-theoretical perspectives and applications in multi-cultural contexts (pp. 357-392). New York: Springer.

Koppes, L.L. (2014). Historical perspectives in industrial and organizational psychology. New York: Psychology Press.

Lefkowitz, J. (2005). Values of industrial-organizational psychology: Who are we? The Industrial-Organizational Psychologist, 43, 13-20.

Lefkowitz, J. (2008). To prosper organizational psychology should... expand its values to match the quality of its ethics. Journal of Organizational Behavior, 29, 439-453. http://dx.doi.org/10.1002/job.527

Lefkowitz, J. (2010). Industrial-organizational psychology's recurring identity crises: It's a values issue. Industrial and Organizational Psychology, 3(3), 293-299. http:// dx.doi.org/10.1111/j.1754-9434.2010.01243.x

Lefkowitz, J. (2016). News flash! Work psychology discovers workers! Industrial and Organizational Psychology, 9(1), 137-144. http://dx.doi.org/10.1017/iop. 2015.126

Lussier, R.N., \& Hendon, J.R. (2015). Human resource management: Functions, applications, and skill development. Newbury Park, CA: Sage.

Miles, M.B., \& Huberman, A.M. (1994). Qualitative data analysis. Thousand Oaks, CA: Sage.

Miller, A.L., \& Lambert, A.D. (2014). Open-ended survey questions: Item nonresponse nightmare or qualitative data dream? Survey Practice, 7(5), 1-18.

Morelli, N., Illingworth, A.J., \& Handler, C. (2015). Questions about IO psychology's future. Industrial and Organizational Psychology, 8(2), 269-276. http://dx.doi. org/10.1017/iop.2015.32

Moyo, N.T. (2012). IOP in South Africa: Research and practice. Unpublished masters dissertation, University of the Witwatersrand, Johannesburg, South Africa.

Muchinsky, P.M. (2003). Psychology applied to work. (7th edn.). Belmont, TN Thomson Wadsworth.

Olson-Buchanan, J., Bryan, L.K., \& Thompson, L.F. (2013). Using industrialorganizational psychology for the greater good: Helping those who help others. New York: Taylor \& Francis.

Page, B. (2015). Exploring professional identity of industrial psychologists. Unpublished masters dissertation, University of Johannesburg, Johannesburg, South Africa.

Petticrew, M., \& Roberts, H. (2006). Systematic reviews in the social science: A practical guide. Oxford, UK: Blackwell.

Reja, U., Manfreda, K.L., Hlebec, V., \& Vehovar, V. (2003). Open-ended vs. close-ended questions in web questionnaires. Advances in Methodology and Statistics (Metodološki zvezki), 19, 159-177.

Rothmann, S., \& Cooper, C.L. (2015). Work and organizational psychology. Oxford, UK: Routledge Publishers.

Ryan, A.M. (2003). Defining ourselves: IO psychology's identity quest. The IndustrialOrganizational Psychologist, 41(1), 21-33.

Ryan, A.M., \& Ford, J.K. (2010). Organizational psychology and the tipping point of professional identity. Industrial and Organizational Psychology, 3(3), 241-258. http://dx.doi.org/10.1111/j.1754-9434.2010.01233.x

Salkind, N.J. (2012). Exploring research. (8th edn.). Salt River, NJ: Pearson Publications.

Saris, W.E., \& Gallhofer, I.N. (2014). The structure of open-ended and closed survey items. In W.E. Saris \& I. N. Gallhofer, Design, evaluation, and analysis of questionnaires for survey research (pp. 121-136). Hoboken, NJ: Wiley.

Schaerer, M. (2011). Affirming psychology in industrial psychology. Unpublished masters dissertation, University of Johannesburg, South Africa.

Schleicher, D.J., Greguras, G.J., Highhouse, S., Marks, M.A., Slaughter, J.E., \& Tesluk, P.E. (2006, May). Making the move from psychology to b-schools: Issues to consider. Panel discussion presented at the 21st Annual Conference of the Society for Industrial and Organizational Psychology, Dallas, TX.

Schreuder, D., \& Coetzee, M. (2010). An overview of industrial and organisational psychology research in South Africa: A preliminary study. SA Journal of Industrial Psychology, 36(1), 1-11.

Spector, P.E. (2012). Introduction: General versus specific measures and the special case of core self-evaluations. Journal of Organizational Behavior, 33(2), 151-152. http://dx.doi.org/10.1002/job.762

Strümpher, D.J.W. (2007). Lest we forget that industrial and organizational psychology is psychology. South African Journal of Industrial Psychology, 33(1), 1-7.

Terre B.M., Durrheim, K., \& Kelly, K. (2006). First steps in qualitative data analysis. In M. Terre Blanche, K. Durrheim, \& D. Painter (Eds.), Research in practice: Applied methods for the social sciences (pp. 321-344). Cape Town, South Africa: University of Cape Town.

Van Tonder, C. \& Roodt, G. (Eds.) (2008). Organisation development: Theory and practice. Pretoria: Van Schaik Publishers.

Van Vuuren, L.J. (2010). Industrial psychology: Goodness of fit? Fit for goodness? South African Journal of Industrial Psychology, 36(2), Art. \#939, 1-16. http:// dx.doi.org/10.4102/sajip.v36i2.939 
Van Zyl, L.E. (2013a). Towards the future: I/O psychology in South Africa. Invited paper presented at the Third Annual Student in Psychology Conference, Johannesburg.

Van Zyl, L.E. (2013b). Research methodology for economic and management sciences. Upper Saddle River, NJ: Pearson Education International.

Van Zyl, L.E. (2015). Power and politics. In S.P. Robbins, A. Odendaal, \& G. Roodt (Eds.) Organizational behaviour: Global and Southern African perspectives (3rd edn.) South Africa: Pearson Education Southern Africa.

Van Zyl, L.E., Deacon, E., \& Rothmann, S. (2010). Towards happiness: Experiences of work-role fit, meaningfulness and work engagement of industrial/organisationa psychologists in South Africa. SA Journal of Industrial Psychology, 36(1), 1-10.

Van Zyl, L. E. \& Stander, M. W. (2013). A strengths-based approach towards coaching in a multicultural environment. In J. White, R. Motching \& M. Lux (Eds.), Theory and Practice of the Person-Centered Approach - Interconnections Beyond Psychotherapy (pp. 245-257). New York, NY: Springer.

Van Zyl, L.E., Stander, M.W., \& Coetzee, E. (2013a, July). Identity in peril: The current state of industrial psychology. Research paper presented at the 15th Annual Society of Industrial/Organisational Psychologists in South Africa Conference, Pretoria.
Van Zyl, L.E., Stander, M.W., Veldsman, T., Crous, F., Cilliers, F., \& De Waal., B. (2013b, July). The relevance of industrial psychology as a profession and a discipline in South Africa. Research paper presented at the 15th Annual Society of Industrial/ Organisational Psychologists in Conference, Pretoria.

Veldsman, T. (2001). A new playing field, game and/or different rules? Into the future with industrial psychology as a discipline and profession. South African Journal of Industrial Psychology, 27, 34-41. http://dx.doi.org/10.4102/sajip.v27i4.797

Venter, A., \& Barkhuizen, N. (2005). Rethinking undergraduate curricula: A Delphi study human resource management and industrial \& organisational psychology. South African Journal of Industrial Psychology, 31, 46-53. http://dx.doi. org/10.4102/sajip.v31i3.206

Warr, P.B. (2007). Some historical developments in IOP outside the United States. In L.L. Koppes (Ed.), Historical perspectives in industrial and organizational psychology (pp. 81-110). Mahwah, NJ: Lawrence Erlbaum Associates.

Whiston, S.C., Rose, C.S., Peterson, J.M., III, \& Nguyen, C.P. (2013). Content analysis of the journal of career assessment. Journal of Career Assessment, 21(3), 367-377. http://dx.doi.org/10.1177/1069072712475160

Zammito, J.H. (2004). A nice derangement of Epistemes. Post-positivism in the study of science from Quine to Latour. Chicago, IL: The University of Chicago Press. 